\title{
STUDI PEMBUATAN SIRUP JERUK MANIS PASAMAN (Citrus sinensis Linn.)
}

\author{
Rifni Novitasari* \\ *Dosen Teknologi Pangan, Fakultas Pertanian, UNISI \\ rifnivita@gmail.com
}

\begin{abstract}
Abstrak
Telah dilakukan penelitian pada tanggal 01 s/d 18 Oktober 2018 di Laboratorium Pilot Plant, Universitas Andalas, Padang dengan judul "STUDI PEMBUATAN SIRUP JERUK MANIS PASAMAN (Citrus sinensis Linn.)". Penelitian bertujuan untuk mengetahui tahapan-tahapan yang tepat dalam pengolahan jeruk manis dari Nagari Aia Gadang, Kecamatan Pasaman, Kabupaten Pasaman Barat sehingga dihasilkan sirup kemasan dengan citarasa, aroma dan warna yang disukai oleh panelis. Dari beberapa perlakuan pengolahan akhirnya dapat diketahui bahwa hasil pengolahan sirup jeruk dengan cara membuang kulit arid an biji pada daging buah jeruk, dan penambahan CMC $1 \%$, serta penambahan Natrium benzoate $0,02 \%$, dan penambahan gula sebanyak 526,15 gram dengan penambahan pasta sebanyak 21 tetes per $300 \mathrm{ml}$ larutan sari buah menghasilkan sirup jeruk kemasan yang disukai dari segi warna, rasa, dan aroma juga kekentalannya dengan kadar gula $62,4 \%$ yang diukur dengan hand refraktometer.
\end{abstract}

Kata Kunci : Jeruk, Jeruk Manis Pasaman, Sirup Jeruk

\section{PENDAHULUAN}

Indonesia terdapat berbagai macam varietas jeruk. Keragaman jeruk sangat tinggi yang ditunjukan oleh banyaknya anggota pada marga Citrus (Karsinah, dkk., 2002). Meskupun demikian, yang dianggap jeruk yang asli hanya 3 kelompok yaitu : mandarin, jeruk besar dan sitron, sedangkan yang lainnya hasil persilangan dari 3 kelompok tersebut. Kelompok mandarin sendiri terdiri dari banyak spesies yang secara fenotipik berbeda jauh (Barret dan Rhondes, 1976 cit Hajrah, 2009).

Pasaman Barat terkenal dengan hasil buah-buahan yang melimpah, antara lain : buah alpokat, jeruk, salak, durian dan lain-lain. Buah-buahan secara umum mudah mengalami kerusakan mekanis, fisiologis, kimiawi dan mikrobiologis termasuk buah jeruk. Untuk mencegah kerusakan buah tersebut, maka salah satu alternatif untuk mengamankan hasil panen buah-buahan bahkan dapat meningkatkan nilai tambah bagi para petani adalah mengolahnya menjadi sirup yang berbahan baku sari buah (Novitasari, R , 2012)

Jeruk yang dihasilkan di Nagari Aia Gadang, Kecamatan Pasaman, Kabupaten Pasaman Barat adalah jenis jeruk manis. Jeruk manis merupakan jeruk yang banyak digemari karena rasanya yang manis, tanpa ada rasa asamnya. Salah satu usaha untuk memperpanjang umur simpan dan diversifikasi hasil olahan dari buah jeruk adalah mengolahnya menjadi sirup Ini didukung oleh keunggulan dari jeruk itu 
sendiri yang memiliki rasa yang manis, dan kandungan air yang tinggi dibandingkan dengan varietas yang lain. Jeruk manis memiliki kandungan gizi yang tinggi juga dibandingkan dengan jeruk jenis lainnya, misalnya vitamin $\mathrm{C}$ $(53,2 \mathrm{~g})$, vitamin A $(11 \mu \mathrm{g})$, kalsium (40mg) dan antioksidan yang bermanfaat bagi tubuh (Chen et al., 2012 ; Stinco et al., 2013).

Permasalahan dalam proses pembuatan olahan jeruk yang sering dialami oleh para ibu-ibu dhasawisma antara lain adalah rasa pahit yang sering muncul pada sari buah jeruk yang merupakan bahan baku dalam pembuatan olahan jeruk, dan olahan dalam bentuk sirup, sehingga apabila dilakukan pengenceran untuk dikonsumsi maka menghasilkan minuman sirup dengan warna yang sangat pucat dan tidak menarik bagi konsumen. Selain itu, sirup yang dihasilkan memiliki stabilitas larutan yang kurang baik sehingga selama penyimpanan setelah proses produksi sirup yang dihasilkan akan terdispersi menjadi 2 bagian, dimana bagian atas dari sirup dalam botol kemasan memiliki warna yang pucat bila dibandingkan dengan bagian bawahnya.

Berdasarkan uraian di atas, maka dilakukanlah pra-penelitian untuk menghasilkan sirup olahan dari sumber daya alam yang melimpah di Pasaman Barat umumnya dan di Nagari Aia Gadang, Kecamatan Pasaman, Kabupaten Pasaman Barat khususnya, yakni buah jeruk. Pra penelitian ini ditujukan untuk menentukan tahapantahapan proses dan perlakuan yang dirancang untuk menghasilkan alternatif perlakuan-perlakuan yang akan dilakukan dalam proses pembuatan sirup jeruk, yang melibatkan daging buah jeruk sebagai sumber sari buah bahan bakunya.
Pra-penelitian ini juga dilakukan untuk mencari solusi alternatif pemakaian bahan tambahan pangan penstabil yakni CMC (Carboxy Methyl Cellulose) sebagai pengganti penggunakan ekstrak pektin yang diperoleh dari kulit jeruk manis.dengan kadar tertentu sehingga dihasilkan larutan sirup yang homogeny dengan stabilitas larutan yang tinggi.

Dengan dilakukan penelitian ini diharapkan dapat bermanfat memberikan informasi teknologi sederhana tahapantahapan dalam proses pembuatan sirup jeruk manis Pasaman sehingga dapat diterapkan ditengah-tengah masyarakat dalam upaya memanfaatkan sumber daya alam yang melimpah di Pasama Barat pada umumnya dan Nagari Aia Gadang pada khususnya dengan harapan dapat dikembangkan skala Unit Kegiatan Masyarakat (UKM) yang pada akhirnya dapat meningkatkan kesejahteraan anggota UKM baik secara kelompok maupun perorangan.

\section{METODE PENELITIAN}

\section{Bahan}

Bahan baku yang digunakan untuk pembuatan sirup jeruk ini adalah jeruk manis Pasaman (Citrus sinensis Linn) yang diperoleh dari Nagari Aia Gadang, Kecamatan Pasaman, Kabupaten Pasaman Barat, gula pasir, asam sitrat $0,1 \%$ dari sari buah, Natrium benzoate $0,02 \%$ dari sari buah, Pasta orange merk Koepoe-Koepo.

\section{Alat}

Adapun peralatan yang digunakan pada proses pembuatan sirup jeruk manis pasaman ini adalah : pisau tahan karat, talenan, alat pengepres sari buah, saringan, kompor gas, wajan anti lengket, gelas ukur, timbangan, corong 
air, dandang sterilisasi, botol, pipet tetes, pengaduk/spatula, infrared thermomether, $\mathrm{pH}$ meter, dan hand refractometer.

\section{Metode Penelitian}

Pada penelitian ini, dilakukan beberapa percobaan alur produksi sirup kemasan dengan cara membedakan perlakuan dari bahan baku yakni buah jeruk yang akan digunakan. Adapun perlakuan tersebut dengan membedakan cara untuk mendapatkan sari buah jeruk yang akan diolah menjadi sirup kemasan dengan cara antara lain :daging buah yang digunakan dan dipress dengan alat pengepressan sari buah khusus jeruk ada yang hanya dibuang biji buah, ada yang dibuang biji buah dan kulit sari buah. Sedangkan perlakuan lain adalah dengan ada atau tanpa penambahan CMC sebagai penstabil, penambahan natrium benzoate sebagai pengawet dari larutan sirup yang dihasilkan.

Disamping itu dilakukan beberapa metode untuk menetapkan jumlah gula dan pasta orange yang ditambahkan dengan tujuan pengawetan dan mempengaruhi cita rasa dari sirup jeruk kemasan yang dihasilkan.

\section{TINJAUAN PUSTAKA}

\section{Jeruk Manis}

Indonesia terdapat berbagai macam varietas jeruk. Keragaman jeruk sangat tinggi yang ditunjukan oleh banyaknya anggota pada marga Citrus (Karsinah, dkk., 2002). Meskupun demikian, yang dianggap jeruk yang asli hanya 3 kelompok yaitu : mandarin, jeruk besar dan sitron, sedangkan yang lainnya hasil persilangan dari 3 kelompok tersebut. Kelompok mandarin sendiri terdiri dari banyak spesies yang secara fenotipik berbeda jauh (Barret dan Rhondes, 1976 cit Hajrah, 2009).
Tanaman jeruk dikenal dengan nama latin Citrus sinensis Linn. Tumbuhan ini merupakan tanaman yang dapat tumbuh di daerah tropis dan subtropis. Jeruk manis dapat beradaptasi dengan baik di daerah tropis pada ketinggian 900 - 1200 meter dpl dan udara senantiasa lembab, serta mempunyai persyaratan air tertentu (Rismunandar, 1996). Tanaman jeruk manis dapat mencapai ketinggian 3-10 m. Tangkai daun $0,5-3,5 \mathrm{~cm}$. Daun berbentuk elips atau bulat telur memanjang. Buah jeruk berbrntuk bulat atau bulat rata dan memiliki kulit buah yang tebal $(0,3-0,5 \mathrm{~cm})$, daging buah kuning, jingga atau kemerah-merahan. Biji jeruk berbentuk bulat telur dan berwarna putih atau putih keabuan (Steenis, 1987).

\section{Klasifikasi Jeruk Manis}

Jeruk manis disebut juga jeruk peras mempunyai nama ilmiah Citrus Sinensis Linn. Klasifikasi tanaman jeruk manis sebagai berikut :

\begin{tabular}{|c|c|}
\hline Kingdom & : Plantae (tumbuhan) \\
\hline Subkingdom & $\begin{array}{l}\text { : Tracheobionta } \\
\text { (tumbuhan berpembuluh) }\end{array}$ \\
\hline Super devisi & $\begin{array}{l}\text { : Spermatophyte } \\
\text { (menghasilkan biji) }\end{array}$ \\
\hline Devisi & $\begin{array}{l}\text { : Magnoliophyta } \\
\text { (tumbuhan berbunga) }\end{array}$ \\
\hline Kelas & $\begin{array}{l}\text { : Magnoliopsida } \\
\text { (berkeping dua / dikotil) }\end{array}$ \\
\hline Sub kelas & : Rosidae \\
\hline Ordo & : Sapindales \\
\hline Family & $\begin{array}{l}\text { : Rutaceae } \\
\text { (suku jeruk-jerukan) }\end{array}$ \\
\hline Genus & : Citrus \\
\hline Spesies & : Citrus sinensis L \\
\hline
\end{tabular}

\section{Varietas Jeruk Manis}

Jeruk manis dalam bahasa inggris disebut sweet orange, yang dikonsumsi sebagai buah peras. Disebut jeruk manis 
karena rasanya manis, tetapi ada juga yang disertai asam sedikit, sehingga bisa menambah rasa segar bila dimakan atau diminumsebagai sari buah. Jeruk manis mempunyai banyak jenis atau varietas. Dari keragaman jenis atau varietas yang tersebar di berbagai negara, jeruk manis dapat dikelompokkan sebagai berikut :

1. Jeruk manis Biasa (Common Orange)

Jeruk manis golongan ini ditandai dengan buahnya yang berwarna kuning atau kombinasi antara kuning dan merah, tekstur dagingnya kasar, mengandung biji, sangat produktif berbuah, rasa manis buahnya segar agak asam dan berumur panjang. Termasuk ke dalam golongan jeruk ini adalah jeruk manis varietas Valencia, Hamlin, Pineapple, Shamouti dan Tenerife.

2. Jeruk Manis Pusar (Navel Orange)

Jeruk manis golongan ini mempunyai ciri khas yang terdapat pusar (udel) di ujung buahnya, daging buah umumnya tidak berbiji, bertekstur rapuh, dan segmennya mudah dipisah. Termasuk golongan jeruk ini antara lain adalah varietas atau kultivar Wangshington Navel Orange (WNO), Thompson Navel Orange, dan Baianinha Picacicaba.

3. Jeruk Manis Merah Darah (Pigmented Orange)

Semua bagian buah jeruk manis golongan ini (kulit, daging, buah, dan cairan sari buah) bewarna merah akibat pigmen antosianin. Termasuk golongan jeruk manis ini adalah varietas Maltaise Sanguine, Double Fine ameloree, DoubleFine dan Entrefine.

4. Jeruk Manis Tanpa Rasa Asam (Acidless Orange)

Jeruk manis golongan ini buahnya kasar dengan asamnya sangat rendah. Termasuk kedalam golongan jeruk manis ini adalah varietas Imperial, Lima, Maltes dan Sukkari.

Adapun komposisi kimia jeruk manis secara umum dapat dilihat pada Tabel 1.

Tabel 1. Komposisi Zat Gizi per 100 gram Sari Buah Jeruk Manis

\begin{tabular}{|l|r|}
\hline \multicolumn{1}{|c|}{ Komponen } & Jumlah \\
\hline Kalori (Kal) & 44,0 \\
Protein (g) & 0,8 \\
Lemak (g) & 0,2 \\
Karbohidrat (g) & 11,0 \\
Kalsium (mg) & 19,0 \\
Fosfor (mg) & 16,0 \\
Vitamin A (SI) & 190,0 \\
Vitamin B1(mg) & 0,08 \\
Vitamin C (mg) & 49,0 \\
Air (g) & 87,5 \\
\hline
\end{tabular}

Sumber : Departemen kesehatan RI (1996) 


\section{Sirup}

Sirup adalah sejenis minuman berupa larutan yang kental dengan citarasa yang beraneka ragam. Sirup buah adalah sirup yang terbuat dari bahan baku buah-buahan. Berbeda dengan sari buah, untuk mengkonsumsinya maka sirup buah harus diencerkan dulu dengan air mineral dengan perbandingan sirup dan air berkisar $1: 4$, atau maksimal $1: 5$. Pengenceran dilakukan karena kadar gula dalam sirup ysng terlalu tinggi ysitu antara 55-65\% (Satuhu, 2004).

Sirup juga diartikan sebagai larutan kental yang memiliki kadar gula tinggi terlarut dan tidak memiliki kecendrungan pengendapan Kristal gula (Ahdno et all, 2016 cit Wijana, S et all , 2016).

Prinsip pembuatan sirup secara komersil : melarutkan gula dalam air, menambahkan zat pengawet organik dan pemanis buatan, zat pengental, serta essence dengan pemanasan dan sterilisasi.

Sedangkan secara umum, pembuatan sirup dapat dilakukan dengan cara melarutkan gula dengan kadar gula yang tinggi pada sari buah dengan memperhatikan $\mathrm{pH}$ sari buah berkiisar 3, sehingga saat pemanasan gula (sukrosa) yang ditambahkan akan membentuk gula invers (glukosa + fruktosa) yang tidak mengkristal.

Setelah dilakukan analisa diketahui bahwa sari buah dari jeruk Pasaman Barat memiliki pH 4,09 dan kadar gula $8,4 \%$. Untuk itu dalam pembuatan sirup maka perlu dilakukan penambahan asam (asam sitrat), dan penambahan gula hingga larutan sirup jeruk yang dihasilkan memiliki kadar gula berkisar antara 55\% s/d $65 \%$.

\section{HASIL DAN PEMBAHASAN}

\section{Prosedur Pengolahan}

1. Sterilisasi Botol Kemasan Sirup Jeruk Manis

a. Botol kemasan dicuci dengan sabun cair pencuci piring dengan bantuan sikat pembersih botol untuk membersihkan bagian dalam botol .

b. Kemudian botol dibersihkan dengan air kran yang mengalir sambil diguncang-guncangkan dengan tujuan membersihkan dan membilas bagian dalam dari botol tersebut, lalu ditiriskan dalam keadaan terbalik diwadah ember.

c. Air dimasak di dalam dandang yang besar dan dalam, sebaiknya melebihi tinggi dari botol yang akan disterilisasi.

d. Botol kemudian dimasukan dalam keadaan terbalik dengan tujuan agar air panas atau uap air dapat mencapai bagian dalam dari botol, sehingga sterilisasi maksimal terhadap botol kemasan dapat tercapai.

e. Setelah air mendidih, biarkan selama \pm 15 menit lagi proses sterilisasi botol .

f. Botol kemudian dikeluarkan dengan bantuan penjepit botol.

g. Tiriskan botol dalam keadaan terbalik dalam ember bersih, setelah kering langsung balikkan posisi botol dan tutup

2. Pembuatan Sirup Jeruk Manis

a. Jeruk manis disortir terlebih dahulu, sehingga jeruk yang cacad secara fisik (memar, atau ada tanda terlalu matang hingga lunak karena proses pembusukan) tidak dipilih. Buah jeruk dipilih yang masak panen. Menurut Rouseff (1990), rasa pahit akibat. senyawa limonin akan 
berkurang dengan meningkatnya kematangan buah jeruk

b. Jeruk hasil sortasi kemudian melalui proses pencucian, lalu ditiriskan dan dikeringkan. Pengeringan dilakukan dengan bantuan kain bersih untuk melap jeruk tersebut.

c. Jeruk kemudian dibelah melintang, lalu dengan bantuan pisau kecil, biji buah dibuang, setelah itu dilakukan pemerasan sari buah. Hal ini bisa dilakukan dengan menggunakan alat yang sederhana seperti alat perasan jeruk dari plastik atau untuk skala IRT dengan menggunakan alat perasan jeruk dengan system ulir.

d. Untuk lebih bersihnya sari buah yang dihasilkan, maka sari buah yang dihasilkan disaring lagi dengan menggunakan saringan.

e. Tiap $300 \mathrm{ml}$ sari buah yang dihasilkan, maka ditambahkan \pm 1 sdt asam sitrat sebagai cara untuk mengkondisikan sari buah menjadi $\mathrm{pH}$ nya menjadi 3 .

f. Kemudian dilakukan pengenceran sari buah ke dalam gelas berukuran $200 \mathrm{ml}$, dengan cara memasukkan $2 \mathrm{sdm}$ sari buah dan melarutkannya dengan air mineral hingga seukuran penyajian air minum umumnya.

g. Untuk mendapatkan warna dan rasa manis yang pas pada sirup jeruk yang dihasilkan nanti, maka dilakukan hal-hal sebagai berikut:

\section{$\checkmark \quad$ Terhadap Rasa}

Rasa manis pada larutan sirup siap saji memiliki kadar gula berkisar antara $12 \%-15 \%$. Maka untuk itu ditambahkan sesendok demi sesendok gula pada larutan sari buah dan dilihat derjat Brix pada hand refraktometer.
2 sdm sari buah setelah ditimbang beratnya $13,4 \mathrm{gr}$.

Setelah penambahan $2 \mathrm{sdm}$ gula (24,6 gr), kadar gulanya menjadi $12,5 \%$, mendekati tingkat range kadar manis larutan sirup tadi, yakni $12 \%$ - $15 \%$.

Jadi untuk sisa sari buah yang ada dari $300 \mathrm{ml}$ tadi, maka ditambahkan gula pasir sebanyak $21 \mathrm{sdm}$.

\section{$\checkmark$ Terhadap Warna}

Kembali pada langkah pengenceran 2 sdm sari buah, setelah kita encerkan sari buah menjadi 1 gelas minuman siap saji, lalu dengan percobaan ditambahkan pasta orange setetes demi setetes. Dan berdasarkan uji coba dilaboratorium diketahui bahwa penambahan 1 tetes pasta sari buah orange lebih disukai berdasarkan uji organoleptik. Maka untuk sari buah yang tersisa ditambahkan 21 tetes pasta sari buah orange.

Jadi untuk $300 \mathrm{ml}$ sari buah ditambahkan asam sitrat sebanyak $1 \mathrm{sdt}$ (5 gr) dan gula sebanyak 526,15 gr, lalu dimasak hingga 30 menit (disini diharapkan saat pemanasan gula (sukrosa) yang ditambahkan akan membentuk gula invers (glukosa + fruktosa) yang tidak mengkristal), setelah mendidih, ditambahkan pasta orange sebanyak 21 tetes. Setelah mendidih dan kompor dimatikan, didinginkan sesaat sirup yang dihasilkan, setelah itu dimasukkan ke botol kemasan dengan memperhatikan headspace larutan sirup, kemudian tutup botol, dan pasteurisasi produk kemasan dilakukan, dimana botol yang sudah terisi dipasteurisasi dengan memasukannya ke dalam wadah yang berisi air yang telah 
dipanaskan dan mencapai suhu $75^{\circ} \mathrm{C}$ selama 30 menit. Kemudian botol dikeluarkan dan didinginkan dengan cara disemprotkan dengan air mengalir / diletakkan ke dalam bak air hingga suhunya mencapai $40^{\circ} \mathrm{C}$.
Proses pembuatan sirup tersebut dapat dilihat pada Gambar 1, sedangkan diagram alir pembuatan sirup dapat dilihat pada Gambar 2.

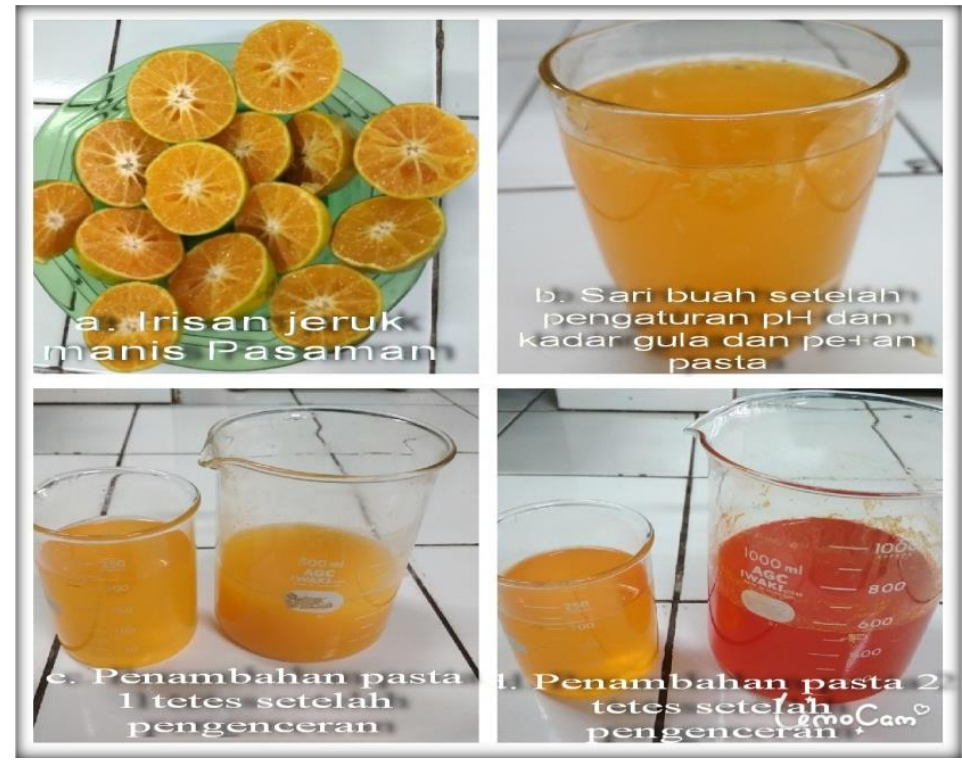

Gambar 1. Proses Pembuatan Sirup Jeruk

\section{KESIMPULAN}

Jeruk manis Pasaman memiliki rasa pahit apabila dilakukan pengolahan terhadap daging buah jeruk tersebut. Rasa pahit dan kelat yang terdapat pada sari buah hasil perasan dan pengolahan sari buah melalui proses pemasakan / pemanasan disebabkan oleh adanya senyawa naringin. Selain itu rasa pahit juga disebabkan oleh senyawa limonat A ring lakton yang merupakan prekusor pahit dan dapat berubah menjadi limonin (senyawa penimbul rasa pahit).

Dari beberapa perlakuan pengolahan akhirnya dapat diketahui bahwa hasil pengolahan sirup jeruk dengan cara membuang kulit arid an biji pada daging buah jeruk, dan penambahan CMC $1 \%$, serta penambahan Natrium benzoate $0,02 \%$, dan penambahan gula sebanyak 526,15 gram dengan penambahan pasta sebanyak 21 tetes per $300 \mathrm{ml}$ larutan sari buah menghasilkan sirup jeruk kemasan yang disukai dari segi warna, rasa, dan aroma juga kekentalannya dengan kadar gula $62,4 \%$ yang diukur dengan hand refraktometer. 


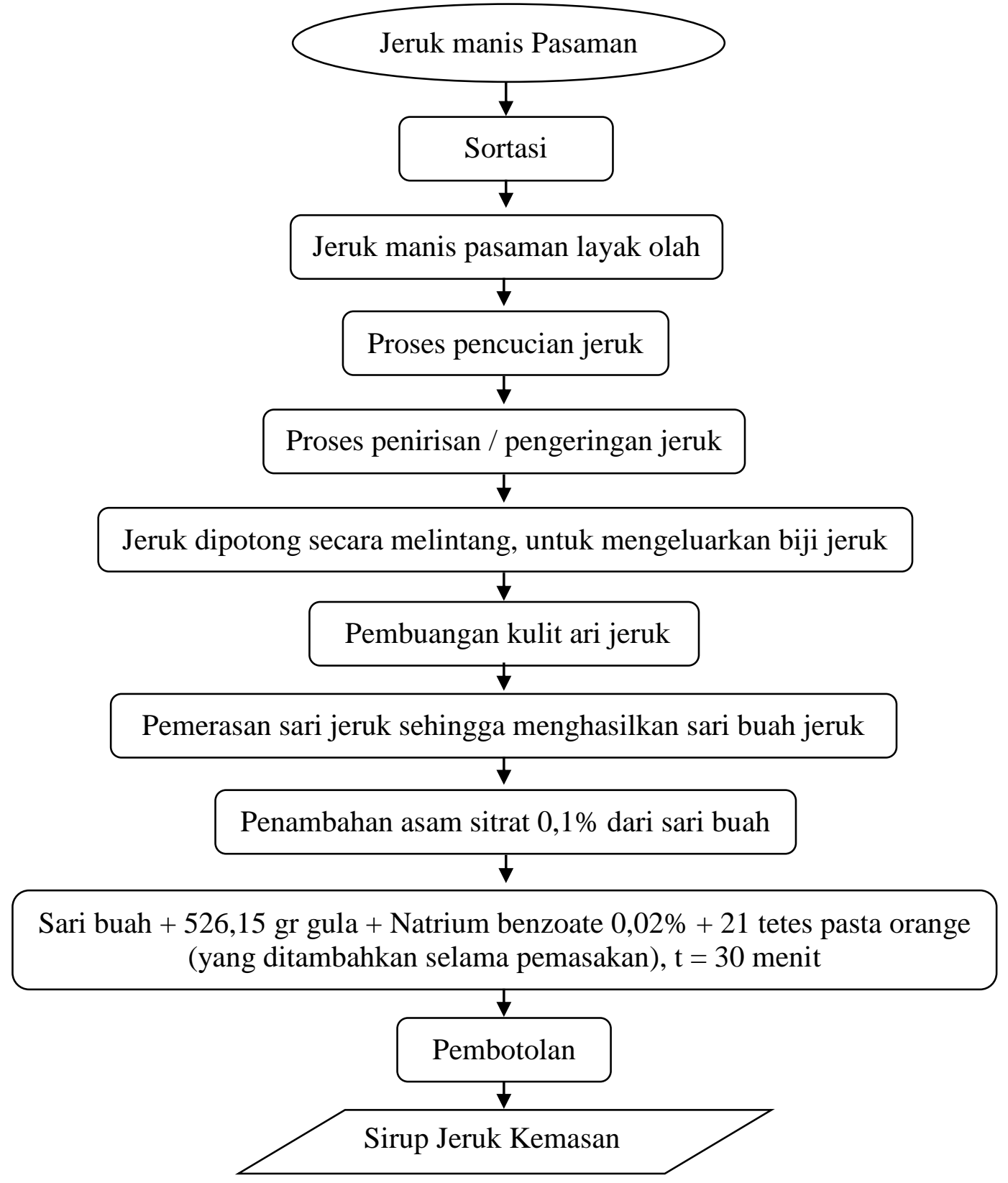

\section{Gambar 2. Diagram Alir Proses Pembuatan Sirup Jeruk}

\section{DAFTAR PUSTAKA}

Dewi, A, K. 2016. Studi Pembuatan Sirup Jeruk Baby Java Subgrade (Kajian Konsentrasi Gula dan Konsentrasi AsamSitrat). Skripsi. UB. Malang.

Hanif, Z, Zamzami, L. 2012. Trend Jeruk Impor dan Posisi Indonesia sebagai Produsen Jeruk Dunia.
Dilihat $20 \quad$ Oktober 2016. $<$ http://balitjestro.litbang.pertanian .go.id/trend-jeruk-impor-dan posisi-indonesia-sebagai-produsen jeruk-dunia/>

Haryoto. 1998. Sirup Jambu Biji. Kanisius. Yogyakarta

Huri. A. 2017. Kandungan Dan Manfaat Buah Jeruk. Dilihat tanggal 18 Oktober 
http://necturajuice.com/kandungan -dan-manfaat-buah-jeruk/

Marta, H, Widyasanti, A, Sukarti, T. 2007. Pengaruh Penggunaan Jenis Gula dan Konsentrasi Saribuah Terhadap Beberapa Karakteristik Sirup Jeruk Keprok Garut (Citrus nobilis Lour). Laporan Penelitian. UNPAD. Bandung.

Mukaromah, U, Susetyorini, S, H, Aminah, S.2010. Kadar vitamin C, mutu fisik, $\mathrm{pH}$ dan mutu organoleptik sirup rosella(Hibiscus sabdariffa L.) berdasarkan cara ekstraksi. Jurnal Pangan dan Gizi 1(1):43-51.

Prastantri, RND. 2011. Analisa Kualitas Organoleptik, Fisik dan Kimia Sirup Biji Tamarillo (Pengaruh Jenis dan Konsentrasi Gula). Skripsi. UB. Malang.
Riadi, AW. 2009. Analisis Kelayakan Produksi Sirup Gula Siwalan dengan MetodeReprosesing Gula Cetak Pada Skala Ganda. Skripsi. UB. Malang.

Rosyidi, D, Purwadi, Harjono, F, T, E. 2007. Penggunaan jus buah jeruk Sunkist (Citrus sinensis) pada pembuatan keju mozzarella. JITEK. 2(1):1-9.

Sutopo. 2015. Teknik budidaya jeruk manis pacitan. Dilihat 16 November 2018. http://balitjestro.litbang.pertanian.g o.id/teknik-budidaya-jeruk-manispacitan/.

Yuwono. S.S. 2015. Buah Jeruk (Citrus sinensis Osbeck). Dilihat 22 Oktober 2018 :http://darsatop.lecture.ub.ac.id/20 15/11/buah-jeruk-citrus-sinensisosbeck/ 